\title{
REVISITING THE US-CHINA TRADE WAR: A STRATEGIC ASSESSMENT
}

\author{
Ramla Khan ${ }^{1}$ \\ Zaeem Hassan Mehmood ${ }^{2}$
}

\section{Introduction}

Zhaohui Wang argues in his paper “Understanding Trump's Trade Policy with China: International Pressures Meet Domestic Politics" that Trump's trade policy with China is fundamentally driven by the increasingly competitive US-China relationship, which influenced Trump's perception of China as America's primary strategic competitor and concern with the US trade deficit, and reinforced by the Trumpization of the Republican Party under the US domestic polarization (Wang 20I9). John Conybeare defines trade war as an international conflict in which "states interact, bargain, and retaliate primarily over economic objectives directly related to the traded goods or service sectors of their economies, and where the means used are restrictions on the free flow of goods or services" (Bastos 20I7).

The research is created to study the interpretation of the policy of trade war in international relations. It aims to diagnose that what global analysts and other states presume of a certain country when it undergoes a trade war, that is what were the takes of the international world when the United States of America- the leading superpower being under security dilemma and petrified from alleged peaceful rise of China. Moreover, it seeks to understand the mindset and comprehension of a leader in the external grounds who undergoes the policy of tariffs against another state. The paper explores how conflict is a consequence of international rivalry as well as domestic-political reasons.

I PhD Scholar in International Relations from National Defence University, Islamabad. Her writings on contemporary global affairs have appeared on national and international policy platforms.

2 PhD Candidate in International Relations and Political Science at Greenwich University, Karachi. He has served as a Research Associate at the National Institute of Maritime Affairs, Pakistan. 


\section{Research Methods}

The opinions of leading experts in trade, commerce and foreign policy have been studied to reach a reasonable evaluation of US China Trade War. The qualitative method of analysis is adopted throughout the paper. For this purpose the perspectives from multinational institutions and reputed think tanks have been gathered from their publications journal articles, surveys and charters. Moreover, due to the inclination or biasness towards one state's view, alternative outlooks on the subject-matter have been studied particularly from Europe and East Asia to explore several approach and perspective. The scenario is then assessed under the framework of "Rational Choice Theory" employed by a number of political economist and experts from the times of Adam Smith who based his masterpiece "Wealth of Nations" on the basis of this model.

Karen Thierfelder observes that "since the beginning of 2018 , the United States has introduced new tariffs on imports from several trading partners citing national security concerns, unfair trade practices, or serious injury to domestic industries" (Devarajan et al 20I8). However later an exclusive list was sorted to cast tariffs upon the imports from China which later followed a reprisal policy. It is now an ordinary ritual to assess the trade policies as an extension of a political process that does not necessarily give rise to aggregate welfare maximization (Razin 20II). US is alleged to use elements of trade war prior in history to revamp the economy in the period of Great Depression (Fearon and Crafts 2013). Smooth Hawley tariffs bill was first passed by the American Congress under President Herbert Hoover on June I7, I930 (Crucini 2003). In the contemporary times, Washington is has applied protectionist laws against its trading partners. For instance, Mexico has been the subject of trade wars due to the immigrant issue.

\section{Trade Wars in International Relations}

In international relations a trade war is when one state apply and surge tariffs to increase the cost of shipping goods across borders causing the other to respond, in a tit-for-tat pattern in which the other nation and foreign countries retaliate with similar forms of trade protectionism (Melese et al I989). Throughout history, states have undergone trade wars whose outcomes were less supported domestically as well as globally.

In the sphere of realism, a trade war is classified as an egoistic-selfish 
strategy adopted by the respective competitor countries. The states involved in the process perform as an introvert entity dominated with the mercenary gains. The national interests of the country are put forth over the global welfare as the political leadership accounts only for domestic interests and the growth of its economy. The trade war can be further contemplated in a contrast approach to "beggar thy neighbor" which the notable economist Adam Smith criticized in his book "Wealth among Nations" (Geisst 2013). The approach also accounts for private profit of a certain party while neglecting the others. "Beggar thy neighbor refers to economic and trade policies that a country enacts that end up adversely affecting its neighbors and/or trading partners" (Hayes 202I).

In addition a trade war likewise involves the application of tariffs for personal gains and exploitation of other challengers. When the superpower faces an economic security dilemma from a rising power, it is most likely that a trade war will be launched against it to curb its growth. In relevance of the evidenced several events of the past, the season of trade wars have been construed by international relations analyst as "a twelve-days Christmas" as in the initial stages the states enjoy its incentives and certain privileges however in the longer run the situation keeps on deteriorating. It is estimated that the competition might not leave winners at the end but opportunities for non-party entities to the conflict. In the recent literature, terminologies like collateral damage that according to Georg Meggle means "a damage which in contrast to the intended aim of the action that brought this damage about, was not intended" (Schwenkenbecher 20I4) and domino effect "when you make a change to one behavior it will activate a chain reaction and cause a shift in related behaviors as well"(Clear 2020) have been used consecutively with the idea of the trade war.

\section{The US Trade War With China}

The onset of an official US trade war with the People's Republic of China is located in the year 20I8. However, some analysts strongly share the view that the trade war had already begun long before during the Obama Administration when in the year of 2010 Beijing surpassed Washington taking away its title of "largest manufacturing nation in the world" or probably when China attained membership in World Trade Organization in 200I (Feng 2006).

The Washington trade war plan against Beijing has substantially faced negation since even before it was just crafted. Advisors in the White House did not feel content with the then President Trump decision to launch a tariff 
scheme against China, an economic powerhouse of the globe. There has been speculation that Mr. Gary Cohn, Chief Advisor in Trump Administration, a supporter of free trade, was enraged by Mr. Trump's plans to impose tariffs on aluminum and steel imports which became a reason for his resignation on March 6, 20I8. He marked that Trump's trade war with China would backfire and impact the US economy negatively, according to the former chief economic adviser who served as Director of the National Economic Council (NEC) in President Donald Trump's administration (BBC 20I9). Trump during his term of office criticized even partners and allies such as Germany for its commercial relations with PRC. In the words of Mohamad Zreik, "surprisingly Europe did not agree with Trump's economic policy toward China, and asked him to back down, and with this American strategy, the Europeans became closer to China and weaving an economic alliance" (Zreik 2020).

It is argued that the hostile relations between the two entities have always endured, however the Trump administrations verdict to program a reprisal of a hefty trade- tariff war against China has given a new face to the US-China relations which is unlikely to undergo a prompt backlash without patch up by the new administration in charge of the White House. Prasenjit $\mathrm{K}$. Basu contends that a dangerous shadow has been casted on the global order by Trump's brinkmanship and the threat of a "new Cold War" would not benefit any state. Likewise, several international relations scholars, including Pinkai points out to the fact that the trade war phenomenon and decision is a perilous option leaving no victories (Basu and Bhattacharya 20I8).

Consequently, it can be easily seen that in the international world and relations the idea of a US China trade war is badly regarded as a trounce and an unappreciated approach. Guoyong Liang from Economic Affairs Officer, Investment and Enterprise Division, United Nations Forum on Trade and Development (UNCTAD) in his recent book indicates: "Trade war may bring unpredictable risks to both economies. More importantly, we should not only look at trade issues, economic figures and static effects, but also consider indirect impacts, political implications and long-term consequences" (Liang and Ding 2020). Vivekananda International Foundation -VIF (Delhi-based think tank) affiliated Maj Gen PK Mallick also draws an analogous analysis: "Tariffs are a very poor instrument for punishing China for any unfair trading practices" (VIF 20I8). He rationalizes that the parallel cost is paid by both ends particularly by the nationals and local agencies. His script claims: When a large country such as the US imposes tariffs, the pain is shared between consumers who pay higher prices and producing firms abroad who have to absorb lower profit margins. The burden of the costs will be carried by: 
I. American consumers.

2. American firms that either produce in China or use intermediate products from China.

3. Firms in countries (mostly US allies) that supply China.

4. Chinese firms (mostly private ones)

The same analysis can be applied to Chinese retaliatory tariffs. Chinese consumers will pay more for soybeans and products like pork that rely on soybeans. Chinese airlines will be less productive if they cannot buy American aircraft. It happens that these US exports have mostly domestic content, so that most of the pain felt by producers will be within the US. There are some sectors in which China's exports consist primarily of domestic value-added (VIF 2OI8).

\section{Conceptual Analysis: Rational Choice}

The Rational Choice theory also known as Rational Decision Making Model (RDMM) is widely used to scrutinize foreign policy decision making (Kahler I998). Its application allows policymakers to figure out drawbacks and advantages of one strategic option from another. The assessment allows in choosing the most beneficial option. For example, pursuits or foreign policy against a certain international agent, in this way picking quite possibly the most advantageous choices.

The US was the sole superpower after the Cold War came to its conclusion, it also had economic supremacy across almost all the major regions. However since China's successful transition and commercial reforms towards the market economy in 1978 and particularly with the reestablished diplomatic ties with Washington in I979- July pact, the total of US-China bilateral trade (exports plus imports) was approximately $\$ 4$ billion (VIF 20I8). It reached $\$ 600$ billion by the year of 2017 . The PRC economy begun to develop and grow more than the US economy. It was perceived as a serious threat to US interest by gaining a large share of international market at the expense of the American economy, whose investors saw manufacturing in China as being more lucrative and cost-effective. Therefore, the US economy started to suffer and so did US position in the global world order. In recent years, China possesses a surplus in bilateral trade with the US and Washington acceptance of the commerce deficit has raised concern among 
American policymakers and public. On the pretext of national security and US interest, Trump's perceived a "trade war" as a pertinent sanctimonious choice to counter Chinese rise and domestic apprehensions. The policy has been the core of his 2017 presidential manifesto "US first. Make America Great Again". For the Trump administration the import/export imbalance with China that raised from US\$ 347 billion 2016 to US \$ 375.2 billion in 2017 was a serious concern (Swenson and Woo 2019). To fix it, the protectionist strategy was seen and claimed as a reasonable and rational decision. However, the Trade War between the US and China has prompted a razor-sharp hostile relationship among the two sides giving seeds to more hostility and competition on various other grounds and grids.

For the US, trade barriers to imports from China is rational as it will safeguard the local industry and abstain manufacturers who are badly hit by cheap Chinese products. This is also the argument put forward by Frederich List in Protectionism Theory, which allows to ease pressure on domestic industry by curtailing international competition. List further argues that it is the right of the government to initiate a policy that would bring economic advancement in their nation. Ironically, Trump claims the same stating that "China must make fair deals with US" (Long 20I6).

Lina Eriksson assumes that in rational choice theory scenario, agents/ states would have consistent long-term preferences (Eriksson 20II). For instance in the case of US-China trade war, the ultimate goal of the US would be to curtail and restrict China's peaceful rise. In doing so it aims to keep an upper hand in the global economy and in the relevant matters. These can include jeopardizing Belt and Road Initiative (BRI) and supporting the states that are antagonistic to China. Therefore, the long term preference of the United States is to contain and impact the peaceful rise of its perceived competitor, Beijing, as a global superpower. So, the trade war is an extension of such American traditional aims to curb Chinese progress and rise. Erickson also states that agents/states are self-interested and rational actors would always seek to maximize their interests. It strictly holds onto the assumption that players in the international community never perform against their national interests. A trade war as specified and explained above is a selfish egoist strategy, adopted to benefit the state's own economy while overlooking the global welfare.

\section{International Agents}

By considering the stance that international agents play an instrumental 
key role in fostering a trade war, this section debates the international factors that are contemplated to be the basis of the US trade war with China.

\section{Enduring Sino-US Enmity}

The Chinese Ministry of Commerce issued a statement saying, "If the US side ignores the opposition of China and the international community, and insists on applying unilateralism and protectionism, the Chinese side will go to the end and will not back down". The trade war could not bother the Chinese peaceful rise, a phrase coined by Zheng Bijian in late 2003 who ensured the world that upsurge of China as a global power would be unique and non-aggressive by all means. Since the changing power equations that seemed to indicate China's economic rise over the US, a number of US Presidents have nurtured efforts to create relativity in Asia to obstruct the placid growth of Beijing. In this relation Washington is since years focused to tie knots with Chinese hostiles in its neighborhood. India is one of these chosen surrogate state to curb Sino influence in the region. However, the peaceful rise could not be challenged and destroyed.

The contemporary literature from West and East are also envisioning the new rise and shift in the polar networks which strengthens more animosity in American policy makers and authorities. It alarms the Pentagon on and off to drive its policies to contain the PRC. The trade war was a precautionary measure in this respect. Barry Buzan decentered globalism, Yan Xuetong's estimation of polarity shake in upcoming years in his book "Leadership and the Rise of Great Powers" and John Mearsheimer's multipolarity signals are adequate to put Washington in security dilemmas. Wang Shouwen, China's deputy trade minister, said China did not want a trade war with the United States but was ready for the war if it happened. Likewise, there are existing interpretations of American president Joe Biden in office as shown by this statement, "There is nothing inevitable about a conflict with China" (BBC 202I).

\section{US Grievances and the WTO}

A number of accounts present certain events that had facilitated the rise and hype of Beijing as an economic giant which became the grievances of the latter party, the US. For instance as mentioned above, China's entry into the World Trade Organization in December 200I was a huge issue, as it was expected that the WTO membership would ease the communist nation's transition to a liberal economy within the rules based system US intended 
and implemented. However, the scenario turned out to be opposite of what the Pentagon had hoped. WTO membership came as a significant opportunity China to win a place in the First World decision-making halls, an obvious threat to Washington's global autonomy (Chan, Lee and Chan 2008).

The WTO is accused of facilitating Beijing's state-driven mercantilism to flood the other international states with their cheap exports, while at the same time impeding foreign access to its own markets (Schlesinger, 20I7). It is being said that the organization has failed to penalize the Chinese government against its illegal practices of high tariffs and domestic content theft. It is accused to force American companies to transfer intellectual property in order to access Chinese markets (Bacchus, Lester and Zhu 20I7). Peter Navarro, a trade adviser to President Donald Trump, projected in an interview "The message to the WTO from this administration has been clear. Things have to change" (Schlesinger 20I7). In the existing international order, the United States sees itself as being on the moral high grounds and aims to coerce China to abandon its policies on high-tech manufacturing and the transfer of technology from foreign companies in order to preserve its global dominance.

In this perspective it is considered that Washington is deliberately fracturing the long standing institution existence, since it could not achieve the desired outcomes from it. Particularly by hindering the nomination of new appellate body delegates, which can only be made by consensus of all members. Trump sustained in his speeches and in public speaking concerning the organization that it offered an unfair treatment to America. In a 2018 interview, he said, "If they don't shape up, I would withdraw from the WTO”. The World Trade Organization, an institution founded in 1995 has a multilateral system to resolve commerce and economic disputes. It has been a success in achieving mediation among countries and in drawing agreement like North America Free Trade Agreement (NAFTA), European Free Trade Association (EFTA), Asia Free Trade Agreement (SAFTA), Union of South American Nations (UNASUR) and so it could be pointed out that the United States being a staunch member in WTO must have put the conflict appropriately in the organization for resolve. The WTO members are predetermined to the formula that if they deem "fellow-members are violating such trade rules, they will use the multilateral system to settle these disputes instead of retaliating with their own tariff increases". In the above scenario, it could be expected that American authorities should also be held accountable for not fulfilling the policies compelled for its members in WTO and for challenging its sovereignty. In addition, Trump was aware of the several specific complex issues that Washington might face if it embraces the 
WTO resolution process.

The WTO's Dispute Settlement Understanding (DSU) is a costly, legal framework to help resolve conflict between the members. With respect to intellectual property rights allegation upon China solely it would require more than $\$ 300$ to $\$ 600$ billion cost per year. Therefore the rational choice of a business mindset leader was a tariff war against its opponent. Under his administration America is regarded to have had disrespected the sovereignty of the WTO by adopting rules and behaviors of its choice when needed. The body was sidelined in the US China Trade dispute despite knowing the stance that tariffs cannot be applied on member countries. The institution rationale behind giving leverage to PRC for past several years is also due to the certain obligations found in the WTO charter which provides that a developing country is entitled, to a certain extent, to the use of non-market practices to spur economic development (WTO 202I).

Farah N. Jan, an international relations lecturer at the University of Pennsylvania defines the US behavior with the WTO, "When the WTO sides with the US, the Trump administration takes credit and praises the institution" (Jan and Phansalkar 20I9) The literature from China Quarterly of International Strategic Studies scripts the Chinese stance, "As a matter of fact, there is no proof that the Chinese government has formulated or implemented any policy on forced technology transfer; and the notion of "technology supporting China's authoritarian regime" is nothing but a new form of politicization of economic and technological issues. By exaggerating the security risks or even making up the "government backgrounds" of Chinese enterprises like Huawei, the Trump administration attempts to negate the legitimate rights and interests of Chinese enterprises to expand overseas markets" (Sun 20I9).

\section{Washington's National Security Undermining Democracy}

One of the most relevant reasons for the trade war as highlighted above is that the US is a democracy and anyone who projects a threat to its egalitarianism is perceived as a foe to its national security. All the American leaders till the newly elected president Joe Biden, continue to be reactive to any perils against democratic norms. The motto, once a leader, always a leader, explains the current US behavior in which Washington by no means is ready to give up the leadership of the world to any other entity. Whenever such an agent is seemed to take pace in the international system the state aims to curb its rise and growth. This was the issue likewise throughout the US Soviet 
cold war and the US-China relations is a similar case. China an autocratic regime with its own created rules dominated economy started to pull ahead on several platforms particularly in the trade markets, currency and defense. So, this scenario could not be put up with by US authorities and elites. Thus, they tried to knock it down by calling upon China's aggressive postures in the South China Sea, freedom of navigation in international waters and in the multinational organization WTO, which failed to contain Beijing's trade patterns. The United States thus chose the tariff war as the only tool to limit and restrict its economic growth. As Sun Haiyong, Senior Research Fellow at the Center for American Studies:

The United States can hardly reconcile with the rise of a great power with a distinct political system and ideology. With regard to grand national strategy, the Trump administration has regarded China as its most formidable competitor, thus intends to diminish and postpone China's challenge to the U.S. global hegemony by containing the development of China's high-tech industries, starting from ICT represented by $5 \mathrm{G}$ technology, for it plays an important role in the new round of industrial upgrading and that Chinese enterprises have enjoyed much advantage in this field.

\section{Domestic Agents}

Following below, we present the proposed factors that domestically fueled the US-China trade war.

\section{American Rising Trade Deficit}

The unequivocal component that ignited the US protectionist race with China was the raging trade deficit of Washington which has been swelling since the last few decades. The unaddressed balance of trade, BOT played an instrumental role in it (Kenton 2020). The American exports have remained immensely numerous as the country remains less reliant upon indigenous products and appliances at the current moment. The Trump administration justified the application of the trade war as a step to stimulate the American population to consume and purchase national products. One of the unique feature of Beijing's economic policy is its cheap labor that captivates the foreign buyers all over the international market. Even the manufacturers and organizations from developed countries like United States and Europe seek this benefit as they want to create their goods and products on low-cost prices by transferring their materials to Beijing. In doing so the domestic 
labor faces joblessness and unemployment alleged as another Chinese economic tool by Washington. The Sino approach to keep the rates low and supportive for external world holds the flux of commerce limited to one locus. Overall, manufacturing jobs in the United States have declined by about $27 \%$ since I998 (Amadeo 202I). The U.S. deficit is the outcome of American willingness to import manufactured goods and autos. In 2019, the deficit of the country was estimated to reach \$6I7 billion when it purchased \$3.I trillion of goods and services while exporting \$2.5 trillion. Trump initiated a trade war to reduce the U.S. trade deficit which has been the world's largest since I975. Reducing the deficit remained a core part of Trump's plan to create more jobs. He quoted during the electoral campaign: "I am running for President to end the unfairness and to put you, the American worker, first".

\section{Fugure 1: US Trade Deficit with China}

\section{U.S. Trade Deficit With China}

The U.S. trade deficit with China was $\$ 345.6$ billion in 2019.

Total U.S. imports from China: $\$ 452.2$ billion

Total U.S. exports to China: $\$ 106.6$ billion
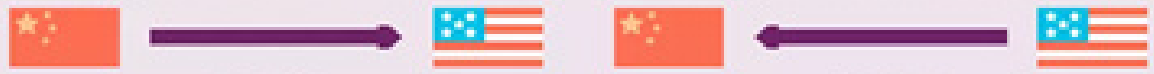

Largest U.S. Imports

Largest U.S. Exports

Computers

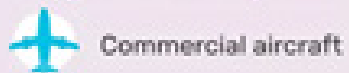

Cell phones

Sopbeans

Apparel and footwear

Semiconductors

China owns $10 \%$ of U.S. public debt to foreign countries.

the balance

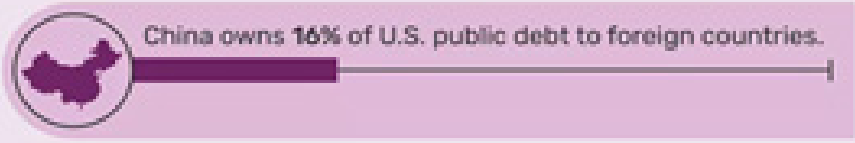

Source: Amadeo (2021).

\section{Donald Trump Presidency}

The conviction that China was flourishing at the interest of the American companies and its conjoined instruments like lending money 
from American treasury and artificial intelligence got impetus and the most emphasis during the Trump's presidency. The 45th elected president of United States of America when coming into power kept promoting one single notion: "We need to reform our economic system so that, once again, we can all succeed together, and America can become rich again. We are going to make America rich again" (Renchon and Suedfeld 202I). This was the core synthesis of the electoral campaigns he ran before winning the White House and taking office on January 20, 2017 (Politico 20I6). He vowed to bash out Chinese threat and its peaceful rise. While speaking in his 2016 electoral campaign, he indirectly defined the American corporations and business class, who in order to get cheap rates had a role in employment reduction from United States. He mentioned; "We got here because we switched from a policy of Americanism - focusing on what's good for America's middle class - to a policy of globalism, focusing on how to make money for large corporations who can move their wealth and workers to foreign countries all to the detriment of the American worker and the American economy. We reward companies for offshoring, and we punish companies for doing business in America" (Schlafly and Decker 2020).

Former president Trump had proclaimed his war on China during his political campaign for the presidency in 2016 . The trade war is interpreted to be one of the most serious events in the history of Sino-American relations which is not likely to lessen any time sooner on both sides. The release of the trade war was pronounced as a catastrophe and a colossal hurdle that the American president Donald Trump created for its own economy, the business class within America and abroad.

He was assured with the belief that former US presidencies have not dealt well with the Chinese commercial lift policies and gave it the opportunity to become a great economic superpower. However he failed to understand the very fact that the correlation among China and the US and between the dollar and the Yuan is based on mutuality and interdependency. One is reliant for exports while China is also endorsing the dollar in its trade dealings and reciprocal impact will be stimulated to Beijing if Washington becomes weak (Zreik 202I). The problem created by the United States is certainly not easy to get out of. Institutions like the WTO could not yet play any influential role in the resolution of this political backed economic tussle. The opinion that the idea of a trade war is less likely to bridge any triumphs is now showing its authenticity when the United States has lost a number of robust competitive trade partners. They have not abandoned their trade cycle with China but also Washington which was a focal point for stockholders and investors is now losing its economic strength steadily. This looks like that point in history 
when businessmen are sorting out other markets than the United States to allocate their finance. As a repercussion of this trade war turmoil, the ranks of the World's Richest People are being reshuffled (Pendleton, Feng and Metcalf 2020). The 500 richest people in the world are losing an average of \$7I billion per day as global financial markets plunge. Harley Davidson, a notable motorbike manufacturing company in the US aftermath the turmoil of tariffs and huge protectionism policies of former American president revealed its scheme of moving to Europe due to Trump's pressures on their business. He said, "We are getting other countries to reduce and eliminate tariffs and trade barriers that have been unfairly used for years against our farmers, workers and companies" he said. "We are opening up closed markets and expanding our footprint. They must play fair, or they will pay tariffs!” (Bredemeier 20I8).

\section{Final Remarks}

The United States initiated trade war is envisaged to shape new realities of the future world. With Joe Biden in office at the White House, it was anticipated that the trade war might come to an end. However, his administration is also committed to the notion to fight against the influence built by China in the market economy. Both sides, the PRC and Washington are not ready to let go of each other at this time. While there is a perception that both parties are suffering equally in the process with no likelihood of victory nevertheless Washington is likely to lose more as it has adopted protectionist methods not only with China but also with other resourceful and often allied states. In the last year alone, the U.S. economy, had lost up to $\$ 7.8$ billion as a result of the trade war. However, China is opening up to Asia and Europe through the BRI, while the US is closing doors and raising taxes to live in economic isolation and a created war itself challenging its values and ideals of capitalism.

Maj Gen PK Mallick (20I8) accounts, "It could derail the current global economic expansion and cripple American businesses that depend on business with China. It could also further complicate geopolitical priorities given the (Trump) administration has enlisted the help of the Chinese in solving the crisis with North Korea”.

As Ryan Rass writes in The Brookings "a candidate in 20I6, Donald Trump built his argument for the presidency around his claimed self-ability as a dealmaker"(Hass and Denmark 2020). The former president being a businessman could not play like a leader. The American economy was thriving but now is struggling to maintain its stake as a superpower in the global 
arena. American businessmen are not used to such an economic situation. A business coalition lobbying campaign called "Tariffs Hurt the Heartland" (Tariffshurt 202I), launched a protest regarding the proposed tariffs right after in September 20I9. The constant decline in manufacturing jobs and the rising trade deficit was seen as justification to initiate a tariff war however the strategy of a trade war has never benefitted a nation before nor is likely to do so.

The US Chamber of Commerce expressed the risks that might arise from this conflict and the possibility of turning into an international trade war. However still the situation can be improved by prompt steps taken via the newly elected Democratic Party President, Joe Biden by aligning his trade outlook and policy with global institutions like World Trade Organization. From I995 to date, the WTO addressed more than 500 similar issues related to subsidies, tariffs or protection measures, among other complaints against member states. The organization succeeds in resolving many differences through mediation and finding a solution that satisfies the parties but will truly require a more viable strategy to deal this hegemonic crisis.

\section{REFERENCES}

Amadeo, K. 2021. "The Real Reason American Jobs Are Going to China". The Balance, April 30, 202I. Retrieved January 02, 202I. https:// www.thebalance.com/u-s-china-trade-deficit-causes-effects-andsolutions-3306277

Bacchus, James; Lester, Simon and Zhu, Huan. 20I7. “Disciplining China's Trade Practices at the WTO: How WTO Complaints Can Help Make China More Market-Oriented". Cato Institute, November 15, 2018. Retrieved December 23, 2020. https://www.cato.org/publications/ policy-analysis/disciplining-chinas-trade-practices-wto-how-wtocomplaints-can-help

Bastos, Maria Ines. 20I7. "Chapter I". In: Winning The Battle To Lose The War? Brazilian Electronics Policy Under Us Threat Of Sanctions. London: Routledge.

BBC. 20I9. "Trump's former top adviser: Tariffs backfiring on US". $B B C$, August OI, 2019. Retrieved January 02, 202I. https://www.bbc.com/ news/business-49187126

BBC. 20i6. "Donald Trump's economic promises". BBC, November o9, 20I6. Retrieved January OI, 202I. https://www.bbc.com/news/ business-37921635 
BBC. 202I. "US-China Relations: Details Released of Biden's First Call with Xi". BBC News, February II, 202I. https://www.bbc.com/news/ world-56021205.

Bredemeier, Ken. 20I8. "Trump Accuses Harley-Davidson of Quitting on America”. VoaNews, June 26, 2018. Retrieved January 02, 202I. https://www.voanews.com/usa/trump-accuses-harley-davidsonquitting-america

Chan, Lai-Há; Lee, Pak K. and Chan, Gerald. 2008. "Rethinking Global Governance: a China Model in the Making?". Contemporary Politics I4, no. I (2008): 3-I9. https://doi.org/Io.I080/I356977080I9I3355.

Clear, J. 2020. "The domino effect: How to create a chain reaction of good habits". Jamesclear, February 03, 2020. Retrieved February 27, 202I. https://jamesclear.com/domino-effect

Crucini, L. 2003. "Tariffs and the Great Depression revisited”. Locgov. Retrieved November I7, 2020. https:/www.loc.gov/item/20056I7037/

Eriksson, Lina. 20II. Rational Choice Theory: Potential and Limits Political Analysis. UK: Macmillan Education.

Fearon, P. and Crafts, N. 2013. The 1930s: Understanding the lessons. The Great Depression of the I930s, 45-73. doi:Io.I093/ acprof:oso/9780199663187.003.0002

Feng, H. 2006. The politics of China's accession to the World Trade Organization. London: Routledge. doi:I0.4324/97802030294II

Geisst, Charles R. 2013. Beggar Thy Neighbor: A History of Usury and Debt (University of Pennsylvania Press, 2013). Access on Feb. 27, 202I. http://www.jstor.org/stable/j.ctt3fhnhv.

Grossman, G., and Helpman, E. I993. Trade Wars and Trade Talks. Harvard Dash. 675-708.doi:10.3386/w4280

Hass, R. and Denmark, A. 2020. "More pain than gain: How the US-China trade war hurt America". Brookings, August 25, 2020. Retrieved January 02, 202I. https://www.brookings.edu/blog/order-fromchaos/2020/08/07/more-pain-than-gain-how-the-us-china-tradewar-hurt-america/

Hayes, A. 20I4. "Beggar-thy-neighbor definition". Investopidia, October 24, 20I4. Retrieved February 27, 202I. https://www.investopedia. com/terms/b/beggarthyneighbor.asp\#: :text=Beggar\%2othy\%2o neighbor\%2orefers\%20to,the\%2oeconomies\%2oof\%2oother\%20 countries

Jan, Farah N. and Phansalkar, Megan. 20I9. “Trump's War on the World Trade 
Organization". The Diplomat, December I2, 20I9. https://thediplomat. com/2019/12/trumps-war-on-the-world-trade-organization/

Kahler, Miles. I998. "Rationality in International Relations". International Organization 52, no. 4 (I998): 919-4I. Access on Jan. I7, 202I. http:// www.jstor.org/stable/2601362.

Kenton, Will. 2020. "Balance of Trade (BOT) Definition". Investopedia, May I2, 2020. October 29, 2020. https://www.investopedia.com/terms/b/ bot.asp

Liang, Guoyong and Ding, Haoyuan. 2020. “The China-US Trade War”. The China-US Trade War, 25-39.https://doi.org/I0.4324/978042934524I3

Long, H. 20I6. "How China doesn't play fair on trade”. CNN, December 07, 2016. Retrieved February 28, 2021. https://money.cnn. com/2016/07/12/news/economy/china-trade-donald-trump/

Mallick, Maj Gen P K. 20I8. "US-China Trade War: Analyses of Deeper Nuances and Wider Implications". Vivekananda International Foundation, September I7, 20I8. https://www.vifindia.org/ paper/20I8/september/us-china-trade-war

Melese, F.; William F. Shughart Ii and Henderson, J. I989. "Tit-ForTat, Tariffs, and Time: A Dynamic Model of Trade Policy". The International Trade Journal 4, no. 2 (I989): I67-86. https://doi. org/ıo.1080/08853908908523689

Metcalf, Tom; Feng, Venus and Pendleton, Devon. 2020. "Wealth Wipeout Reshapes Ranks of World's Richest People”. Bloomberg, March o9, 2020. Retrieved January 02, 202I. https://www.bloomberg.com/ news/articles/2020-03-09/wealth-wipeout-reshapes-ranks-of-worlds-richest-billionaires

NBER. 202I. "Trade Wars: What Do They Mean? Why Are They Happening Now?”. NEBER. Access on February 5, 202I. https://www.nber.org/ system/files/working_papers/w25762/w25762.pdf.

Politico. 20I6. "Full transcript: Donald Trump NYC speech on stakes of the election". Politico, June 22, 2016. Retrieved January 02, 2021. https:// www.politico.com/story/2016/06/transcript-trump-speech-on-thestakes-of-the-election-224654

Prasenjit, B. and Pinaki, B. 20I8. "U.S. China Rivalry Global Impact”. Vifindia. Retrieved December 22, 2020. Available at: https://www.vifindia.org/ sites/default/files/national-security-vol-I-issue-2-colloquium.pdf

Razin, Asaf. 20II. Trade and Tax Policy, Inflation and Exchange Rates: a Modern 
View. Berlin: Springer.

Renchon, S. A. and Suedfeld, P. 202I. Trump Doctrine and the Emerging International System. Cham, Switzerland: Palgrave Macmillan.

Saon, Ray, and Miglani, Smita. 202I. "Implications of US-China Trade War for India". The China-US Trade War and South Asian Economies, 202I, 97-I23. https://doi.org/I0.4324/9781003053613-I0.

Schlafly, P.; Martin; E. and Decker, B. M. 2020. The conservative case for Trump. Washington, DC: Regnery Publishing.

Schlesinger, Jacob M. 20I7. "How China Swallowed the WTO: The U.S helped create the group to smooth global commerce and integrate a rising China: Course Hero". The Wall Street Journal, November Ist, 20I7. Retrieved December 23, 2020. https://www.coursehero.com/ file/4I07288I/How-China-Swallowed-the-WTOpdf/

Schwenkenbecher, A. 20I4. "Collateral damage and the principle of due care". Journal of Military Ethics, I3(I): 94-I05. doi:I0.1080/I5027570.20I4.9 IOOI5

Shantayanan, Devarajan; Go, Delfin S.; Lakatos, Csilla; Robinson, Sherman and Thierfelder, Karen. 2018. "Traders' Dilemma: Developing Countries' Response To Trade Disputes”. Policy Research Working Papers, 2018, 4. https://doi.org/I0.I596/I8I3-9450-8640

Sun, Haiyong. 20I9. "U.S.-China Tech War”. China Quarterly of International Strategic Studies 05, no. 02 (2019): I97-2I2. https://doi.org/IO.II42/ S237774001950012x.

Swenson, Deborah L. and Woo, Wing Thye. 20I9. "The Politics and Economics of the US-China Trade War". Asian Economic Papers I8, no. 3 (2019): I-28.

TariffsHurt. 2021. "Tariffs Hurt the Heartland". Tariffs Hurt Online, n.d. Access on February I6, 202I. https://tariffshurt.com/

Wang, Z. 2019. “Understanding Trump's Trade Policy with China: International Pressures Meet Domestic Politics”. Pacific Focus, 34 (3): 376-407. doi:Io.IIII/pafo.I2I48

WTO. 202I. "World Trade Organization". WTO, access on February I5, 202 I. https://www.wto.org/english/tratop_e/dispu_e/disp_settlement_ cbt_e/ciIsipi_e.htm.

Zreik, M. 2020. “The Dimensions of the US-China trade war". Open Political Science, 3(I): 47-55. doi:IO.I5I5/openps-2020-0004 


\section{ABSTRACT}

Relations amongst the United States of America and the People's Republic of China have historically survived several bouts and rounds. However, the approach employed by the Trump Administration for a program involving reprisal of a hefty tariff-trade war against China has given a new face to the bilateral relations between the two states. The paper demonstrates that domestic and international agents played a vital role in initiating and nurturing the trade clash between Washington and Beijing since 2018 to date. The aim of this study is to ascertain that the political climate and past pursuits of one country, conditions policy outcomes in another, and how domestic political pressures on a politician's defines their relations with foreign counterparts. The paradigm of rational choice theory is adopted to provide a conceptual understanding to the triggering of the trade war between the economic giants.

\section{KEYWORDS}

US Trade-war; PRC; Domestic Agents; International Agents.

Received on April 20, 2021

Approved on May 22, 2021 